\title{
To Feel the Thinking: Affective Procedures of History and Criticism (Today)
}

Katarzyna Bojarska 


\section{To Feel the Thinking: Affective Procedures of History and Criticism (Today)}

DOI:10.18318/td.2017.en.1.3

Thinking is thought through concepts, or functions, or sensations and no one of these thoughts is better than another, or more fully, completely, or synthetically "thought."1

In his lectures from the years 1977-1978 included in the volume Le neutre, Roland Barthes spoke about "a hyperconsciousness of the affective minimum, of the microscopic fragment of emotion... which implies an extreme changeability of affective moments, a rapid modification, into shimmer." ${ }^{2} \mathrm{He}$ had in mind intense,

1 Gilles Deleuze and Felix Guattari, "Percept, Affect, and Concept," in What is Philosophy? trans. Graham Burchell and Hugh Tomlinson (London: Verso, 1994), 198.

2 Roland Barthes, The Neutral, trans. Rosalind E. Krauss and Denis Hollier (New York: Columbia University Press, 2005), 101. I use fragments quoted in Gregory J. Seigworth and Melissa Gregg, "An Inventory of Shimmers," in The Affect Theory Reader, ed. Melissa Gregg and Gregory ). Seigworth (Durham: Duke University Press, 2010). In my description of the role of the affect theory in the humanistic practices I extensively use recognitions presented both in this introduction and in the entire volume. See also the critical review of this volume by Todd Cronan, "The Aesthetic Politics of Affect," Radical Philosophy 172 (2012): 51-53.
The text was written within the project financed by the National Science Centre, grant decision no. DEC-2011/03/B/ $\mathrm{HS}_{2} /-5729$
Katarzyna Bojarska

- Assistant Professor at the Institute of Literary Research of the Polish Academy of Sciences, vice president of "View. Foundation for Visual Culture." She translated i.a. Michael Rothberg's Multidirectional Memory (2016). She is the author of Events after the Event: Białoszewski Richter-Spiegelman (2012). A Fulbright grantee at Cornell University (20092010) and University of Illinois, Chicago (2019). She currently works on troubled pasts and their cultural and artistic reconfigurations within a Horizon 2020 international project. 
so far unexperienced states unfit for divisions established by means of binary oppositions or existing contradictions. They are rather situated between other recognizable states, in intervals; always in relation towards some kind of space, objects, subjects, or times. The project of critical practice emerging from such recognition is a neutral kind of immanent pathos or patho-logy which could create something like "an inventory of shimmers" gathering and arranging into constellations of sensations and affects. It is characterized by "the passion for difference." ${ }^{3}$ Tracing Barthes's thoughts, the affect theory may be perceived as a project of such critique where the passion for difference is cognitive, existential and ethical-political at the same time.

As numerous academic publications of recent years prove, the affect theory serves well not only as a handy frame for several interpretations of constantly emerging practices of cultural life (together with their new media, forms of communication, collective experiences, etc.), but above all - despite many sceptics - as a form of engagement, a critical language, a new instrument of cultural criticism. In opposition to what Hal Foster states, this theory may help the leftist project of fighting the crisis of criticism or even post-criticism. The author of The Return of the Real writes:

Bullied by conservative commentators, most academics no longer stress the importance of critical thinking for an engaged citizenry, and, dependent on corporate sponsors, most curators no longer promote the critical debate once deemed essential to the public reception of advanced art. Indeed, the sheer out-of-date-ness of criticism in an art world that could not care less seems evident enough. Yet what are the options on offer? Celebrating beauty? Affirming affect? Hoping for a "redistribution of the sensible"? Trusting in "the general intellect"? The post-critical condition is supposed to release us from our straightjackets (historical, theoretical, and political), yet for the most part it has abetted a relativism that has little to do with pluralism. ${ }^{4}$

However, how do we perform criticism when we are overwhelmed with the feeling of having exhausted the available repertoire of forms, tricks and strategies; when we feel that well practiced procedures are not working any more the ones we called into being in another, earlier, both academic and historical reality. Foster does not answer this question. Instead, he tries to mobilize

3 Seigworth and Gregg, Shimmers, 11; Barthes, The Neutral, 77.

4 Hall Foster, "Post-critical," October 139 (2012): 3. I would like to thank Ewa Domańska for attracting my attention to this text and its problematic character. 
us to be critical and engaged, applying the often recurring analogy between contemporary times and the 1930s. And if so, let us go back to the problems encountered and to the solutions searched for back then. For example, Bertold Brecht:

Methods become exhausted; stimuli no longer work. New problems appear and demand new methods. Reality changes; in order to represent it, modes of representation must also change. Nothing comes from nothing; the new comes from the old, but that is why it is new. The oppressors do not work in the same way in every epoch. They cannot be defined in the same fashion at all times. There are so many means for them to avoid being spotted. They call their military roads motor-ways; their tanks are painted so that they look like MacDuff's woods. Their agents show blisters on their hands, as if they were workers. No: to turn the hunter into the quarry is something that demands invention. ${ }^{5}$

Working with the affect theory does not mean, and it surely does not have to mean, that contemporary art or literature, or even cultural criticism itself, lost their political significance. It is rather about their political force - and, above all, recognition of their own presence and their political nature which results from other operations and procedures: global political acts concern other areas of experience, impact new aspects of life, control them to an unexpected extent. The overwhelming excess of (both textual and visual) information and the comparably overwhelming scarcity of meaning - "the meaningful meaning" - as well as the necessity of working out new ways of contestation and criticism caused by the present time and the pressure of history made artists, writers, critics, and their addressees look for another area of agreement, influence, and engagement. ${ }^{\mathbf{6}}$ In this context, the key question is about the potentiality of affect, hence the way diverse ephemeral affective stimulations and distractions from the rationally regulated attention and symbolic balance alter affectation (being stimulated) into action (affecting, the possibility of stimulation).

Affect, as Brian Massumi and others have written, is a notion that captures the pre-individual as something common, dynamic and circulating, or even

5 Bertolt Brecht, "Against Georg Lukacs," trans. Stuart Hood, in Aesthetics and Politics (London: Verso, 2007), 83. See also interesting materials collected in the academic magazine Nonsite.org dedicated to Brecht and affects as well as effects, issue 10: "Affect, Effect, Bertolt Brecht" accessed November 18, 2013, http://nonsite.org/issue-10-affect-effectbertolt-brecht/. 
binding. It is a concept that makes it possible to go beyond the body and at the same time understand changing interrelations between different bodies (and in different combinations: human bodies with unhuman ones, unhuman bodies with human ones, etc.), images (produced both by people and by machines), narratives, and so on. Affects, however, as pointed out by a Dutch scholar Mieke Bal, allow us to analyze and be critical about difficult and complex relations between "the wandering notions," between regimes of knowledge production, between various media, disciplines, and finally, between science and art.?

Interest in affect theory in the humanities, therefore, seems to stem from disappointment with available technologies, methods of interpretation, as well as analyses of artworks, epistemology, and politics. However, it also stems from a great urgency to be critical towards one's own moment in history. Reference to the affective dimension of experience indicates such aspect of this experience which is beyond language and which always loses from its specificity in the process of being translated into language. Affect and cognition are not separable; one always thinks through the body (thinking is embodied), while affect is indispensably linked with the life of the body and among bodies. Hence, being in the world and exchanging with its other elements takes place on two levels, separate but unequal: the level of meaning and the level of feeling. Although it is impossible to separate affects and cognition, their relation remains problematic and is continuously tormenting scholars who explore these topics. Theories of affects enable establishing the subject and the community on another basis that is less coherent and stable. Affect appears in-between, in clearances, in cracks, in gaps between communication and mutual understanding, in accumulation of intensity and experiences which - not always fully assimilated - torment our narrative about ourselves, sit somewhere, stuck in photos, in documentation - like spectres in the archives, recorded but not assimilated, registered but not developed.

It is quite commonly believed that the breakthrough moment for affect theory to appear in the field of interest of the contemporary humanities were the $1990^{8}$ (the theory of trauma was also in bloom at the time). Back then

7 See Mieke Bal, Affect as a Cultural Force ( The text was made available by the author for the seminar organized in IBL PAN on October 15, 2013 within the project financed by the National Science Centre, grant decision no. DEC-2011/03/B/HS2/05729: The Affective Turn after 1989. Strategies and Styles of Representation in the Interdisciplinary Research Perspective under the supervision of Prof. Marek Zaleski).

8 This genealogy as well as the attempt to characterize the field of interest in affects by the contemporary humanities, I recreate after Seigworth and Gregg, Shimmers. 
- in 1996, to be precise - two key articles, at least in Anglo-Saxon academia, were published: Brian Massumi's The Autonomy of Affect and Shame in the Cybernetic Field by Eve Kosofsky Sedgwick and Adam Frank. They excited scholars not only because they pushed certain categories in cognitive theory focusing on its affective dimension, locating not only experiences, but also knowledge in the body. They also introduced specific affective operations in the space of the academic text itself - its content and its form. The above mentioned publications immediately enable us to catch the double-track tendency typical of the affective field: one of these tracks follows interpretations of Silvan Tomkins's psycho-biological concepts (Sedgwick, Frank, et al.), while the other draws from Deleuze's reading of Spinoza, but also others' readings of Deleuze and Guattari (Massumi, van Alphen, Val, et. al.). These paths do not really meet and it seems futile to introduce a general profile or to determine parameters of the "turn" in the humanistic research. In this sense, it is not justified to talk about the turn towards affects or the establishment of a new, affective paradigm in the humanities. It appears that this is rather about shifting attention and sensitivity to a slightly different area, about exposing other possibilities of cognition in the world in general and in the world of scientific research; about privileging or showing the value of models so far excluded, seen as worse, and finally, about pointing to new ways of practicing criticism and, just as importantly, new ways of practicing history, including history of literature, art, and theatre.

Consequently, instead of speaking about the turn and establishing an order in the field of the contemporary theory of affects, I will let myself introduce a bit of disorder by indicating diverse branches, tendencies, quasitendencies, and further distinctions which, I hope, will be most explicit about this heterogeneous field.9 They include non-Cartesian or non-humanistic philosophical traditions implemented by avant-garde versions of academic feminism as represented by Rosi Braidotti, Elisabeth Grosz, Moira Gatens, or Genevieve Lloyd; Italian autonomism as represented by Paolo Virno or Maurizio Lazzarato; cultural studies strongly inspired by the philosophy of Massumi, Lawrence Grossberg, Meaghan Morris; or even the philosophy of politics developed by Giorgio Agamben, Michael Hardt and Antonio Negri. Another area are reflections over intimate relations and interconnections between the human and non-human or post-human, phenomenologies and post-phenomenologies of corporeality in the broader field (practiced by such scholars as Vivian Sobchack, Don Ihde, Michel Henry, and Laura Marks). This tendency is linked with the interest in the juncture of what is human with the non-organic and technological. To put it more simply: man

9 Seigworth and Gregg, Shimmers. 6-7. 
and machine. ${ }^{10} \mathrm{~A}$ part of this field may also be constituted by - inspired by psychoanalytical and psychological readings (e.g. projects by Mikkel BorchJacobsen, Cathy Caruth, et al.). A crucial, strongly political or even activist element of this puzzle is developed by male and female feminists, queer researchers, representatives of disability studies and subaltern studies as they reflect on alternative forms of being and co-being as well as experiencing and being political, where efforts are firstly made to formulate alternative concepts of power (Sara Ahmed, Lauren Berlant). Academic practices in the field of the humanities inspired by neurology, life science, physics, and other disciplines (Cathherine Malabou) should be taken into account as well. To many scholars, the crisis of the supremacy of language turned out to be a fundamental one, making them refer to such historical concepts as Raymond Williams's "structures of feeling," Franz Fanon's "third-person consciousness," or Walter Benjamin's non-sensual mimesis, in order to search for what is outside of language, and how things which are pre-, para-, or beyond linguistic meet or even cross with what is sensual (related to touch, taste, smell, etc.), corporeal, connected with stimulations of the nervous system and so on. Such operations should help extend the definition of what is social and cultural, open the ethical-aesthetic space to other subjects who have equal rights to feel and understand. This constellation should be complemented with critical and philosophical discourses of emotion, for example, by Rei Terada or Sianne Ngai. And finally, interest in affect may also turn out to be an emancipatory gesture of the exact science for which what is impossible to be systematized, accidental, astonishing, disorderly is what enforces reflection on the methodological assumptions and the ethics of cognition within the given discipline. ${ }^{\mathbf{1 1}}$

10 An interesting example of implementation of this tendency may be the 2013 edition of Malta Theatre Festival (an interdisciplinary festival, in fact) entitled Oh man, oh machine directed by Romeo Castellucci. See the catalogue under the same title, Poznań 2013.

11 Here we may recall an utterly unfair draft list of publications which contributed to the current shape of the "theory of affect": Exploring Affect: the Selected Writings of Silvan S. Tompkins (1995); Ann Cvetkovich, An Archive of Feeling: Trauma, Sexuality, and Lesbian Public Cultures (2003); Sara Ahmed, The Cultural Politics of Emotion (2004); Charles Altieri, The Particulars of Rapture: an Aesthetics of the Affects (2003), articles of Laurent Berlant, "The Subject of True Feeling: Pain, Privacy, and Politics" (Cultural Studies and Political Theory, 2000); "Love, a Queer Feeling" (Homosexuality/Psychoanalysis, 2001); books by Rosi Braidotti, Metamorphoses: Towards a Materialist Theory of Becoming (2002); Joan Copjec, Read my Desire: Lacan Against the Historicist (1994); Melissa Gregg, Cultural Studies Affective Voices (2006); Eva Illouz, Cold Intimacies: the Making of Emotional Capitalism (2007); Sianne Ngai, Ugly Feelings (2007); Teresa Brennan, The Transmission of Affect (2004); Eve Kosovsky-Sedgwick, Touching Feeling. Affect, Pedagogy, Performativity (2003). The critique of the "affective turn" is presented by Ruth Leys in her extensive article "The Turn to Affect: a Critique," Critical Inquiry 37 (2011): 434-472. 
And now the problems. Because they are there. The first and perhaps the most widespread is terminological confusion. The notion of affect is often used interchangeably and/or as a synonym with emotion or feeling. Emotion however is subjective, a social-linguistic gesture of assigning a certain quality to an experience, which is subsequently defined as being personal. In this sense, emotion is elaborated and modified intensity (affect), a conventionalized and consensual mode of including intensity (affect) into the semantic and semiotic network, into the dynamics of action and reaction which can be narratively structured, and into function and meaning. In other words, it is the intensity (affect) that is identified and taken into possession. On the other hand, feelings are personal and have a biographical nature as they belong to the story (experiences) of a given person, while emotions are social, and affects are pre-personal. A feeling may be thought to be a sensation which, in combination with the current experience of the one who feels it, finds its proper time and name. Everyone, therefore, has their personal archive of sensations from which their emotions originate. Feelings are sincere, while emotions can be faked, or even forged according to the current cultural codes of communication. In such a rough frame, affect is mainly the aforementioned intensity, but in reality its unconscious experience: an abstract, shapeless, and nameless potentiality. Understood this way, affect is situated beyond, or maybe before consciousness, in a single body and between bodies. As a result, affects are evoked by factors that are out of the subject's control, beyond her/ his consciousness and will, but they define the very possibility of our experience and vulnerability to stimuli, and the possibility of processing them. ${ }^{\mathbf{1 2}}$

The last question is about conveying affects (or affecting?). This certainly does not mean that someone's feelings are transfered to another person, simply becoming the latter's feelings. It is rather about staying on the level of the body and its "communicative" structures. Transmission of affect is here pre-symbolic: untamed bodies produce intensities and stimulations, affecting each other. One body enters the other's space of intensity, the sphere of its affective impact, and starts to receive these stimulations, to resonate, then to react.

The primacy of what is affective in a work is marked by the gap between the work's content and effect. ${ }^{\mathbf{1 3}}$ It may be traced in several examples of contemporary literature, plastic arts, dance, or music. To a great extent, the

12 See Deleuze and Guattari, Percept, Affect, and Concept.

13 I wrote about it more broadly in the text Obóz-Muzeum. Afektywna przestrzeń przekazu doświadczenia traumatycznego (i sztuka) which was published in the volume Pamięć w krajobrazie traumatycznym Ekspresja i reprezentacja we współczesnym wystawiennictwie (Kraków: Universitas, 2014). 
aforementioned articles perform such a role, explaining how intensity translates into emotional states. The level of intensity in the reception of a work is not semantically or semiotically ordered, while the order of meaning and the order of intensity seem desynchronized. And this disruption enables another kind of connection between what is separated: not only the content and the effect, but also the form (the way meanings are being constituted) and intensity. Separating the form and the content, the intensity and the effect enables their re-connection on different terms. ${ }^{14}$ Following Gilles Deleuze's thoughts, we may say that affect should primarily serve as an effective detonator of a deep experience and thought resulting from the way it grabs us and forces us to be involved. The feeling becomes a "catalyst" for critical insight. The thought itself becomes less important than the path that leads to it - the sensual impressions that arise during an encounter and demand a different look, an interpretation or transformation, a reworking of current readings. In this sense, it seems that art based on "affective operations," but also interpretation, produces an experience rather than reproduces it.

Translation: Marta Skotnicka

14 Brian Massumi, "Autonomy of Affect," Cultural Critique 31 (1995). 